\title{
A MÜVÉSZETI NEVELÉS TRANSZFERHATÁSAINAK VIZSGÁLATA EGY METAANALITIKUS KUTATÁS KERETÉBEN
}

\author{
MESTERHÁZY MÁRIA \\ az Eötvös Loránd Tudományegyetem Neveléstudományi Doktori Iskolájának \\ doktorandusza \\ dobmester@gmail.com
}

A müvészeti nevelés iránt érdeklődő kutatók, doktoranduszok, tanárok, döntéshozók számára rendkívül érdekes könyv jelent meg 2013-ban, az OECD iLibrary sorozatában. Szerzői: Ellen Winner, a Boston College Pszichológia Tanszékének vezetője, Thalia R. Goldstein, a New York-i Pace University Pszichológia tanszékének asszisztense, valamint Stephan Vincent-Lacrin, az OECD CERI Educational Research and Innovation program koordinátora.

A könyv központi kérdése: „Valóban pozitív hatása van-e a müvészeti nevelésnek az 'innovatív kompetenciák'-ként (innovative skills) definiált képességek három csoportjára: a technikai kompetenciákra, a gondolkodási és kreatív kompetenciákra, valamint a jellemre (viselkedési és szociális kompetenciák)?” (17. o.).

A könyv alapját képező kutatás az OECD CERI ,,Innovation Strategy for Education and Training"projektjének keretében zajlott le. Az innovatív képességek fejlesztése területen ugyanis nagy várakozások fogalmazódnak meg napjainkban a müvészeti nevelés felé. A kutatás alapvető célja ezek kritikus felülvizsgálata volt, amelynek érdekében a szerzők a müvészeti nevelés transzferhatásait vizsgáló, 1950-től napjainkig végzett kvantitatív kutatások áttekintésére és metaanalízisére vállalkoztak. Tíz nyelvterületről 507 kutatást dolgoztak fel, 39 kompetenciaterületen vizsgálódtak a zenei, vizuális, színházi, tánc és sokoldalú (multiarts) müvészeti neveléssel összefüggésben.

A művészeti neveléssel kapcsolatban a politikai döntéshozók által megfogalmazott messzemenő várakozásokra jó példa az alábbi idézet. „A művészeti nevelés fontosabb, mint valaha. A globális gazdaságban a kreativitás létfontosságú. A mai dolgozóknak többre van szükségük, mint képesség és tudás ahhoz, hogy a munkaerőpiac produktív és innovatív résztvevői legyenek. [...] Ahhoz, hogy sikeresek legyünk ma és a jövőben, Amerika gyermekeinek leleményesnek, találékonynak és ötletesnek kell lenniük. A legjobb út ennek a kreativitásnak a támogatásához a müvészeti nevelésen keresztül vezet." (Arne Duncan, PCAH, 2011, 1. p. idézi Winner, Goldstein és Vincent-Lacrin 2013, 23. o.)

Az ehhez hasonló kijelentések arra késztetik a világszerte periferiális helyzetben lévő művészeti nevelés védelmezőit, hogy a müvészet szerepét ne belső értéke- 
iben keressék, hanem külső célokban, például a transzferhatások területén, érvelnek a szerzők. Winner és társai 46 OECD ország kerettantervét megvizsgálva azt találták, hogy ezek legtöbbje számos nem müvészeti tanulási kimenetet sorol fel a müvészeti nevelés célkitüzései között. Például a kreativitást 37 ország jelölte meg a müvészeti nevelés céljaként, a szociális kompetenciákat 31 , a kommunikációs képességeket 29 (53-54. o.).

Az Art for art's sake? kutatási dizájnja alapvetően az úgynevezett REAPprojekt során kidolgozott módszertanra épül. Az 1998-ban kezdődött REAP (Reviewing Education and the Arts Project) a müvészeti nevelés és a tanulmányi eredmények közötti összefüggéseket vizsgálta. (Winner és Hetland, 2001; Hetland és Winner, 2001). Az Art for art' sake? e kutatás eredményeinek időbeli (1998-tól napjainkig) és térbeli (az angolon kívül bevont nyelvterületekre) kibővítése, valamint kiszélesítése (például a szociális és viselkedési kompetenciák területére). A REAP módszertanáról és annak kritikájáról részletesen tájékozódhatunk a kutatás eredményeit bemutató konferencia anyagából (Winner és Hetland, 2001), valamint a Journal of Aesthetic Education 34. számából, melyet teljes egészében a REAP bemutatásának szenteltek.

A módszertan tárgyalását a szerzők a transzfervizsgálatok jellemzésével kezdik. Már ebben a fejezetben, ahogy a könyv során végig, következetesen elkülönítik az ok-okozati és a korrelációs összefüggések vizsgálatát. Az Art for art's sake? részletesen felsorolja azokat az adatbázisokat, melyekben a szerzők az adatgyüjtést elvégezték. A keresés során minden egyes mủvészeti nevelési forma nevéhez társítottak egy innovatív kompetenciával, a páronként átlagosan 350-400 (!) találatból aztán kizárták a nem kvantitatív, valamint a kontrollcsoport nélküli kutatásokat, a müvészeti iskolák programjait, és a zenehallgatás tranzithatásait vizsgáló (ún. Mozart-hatás) irodalmat.

A metaanalizis során kiválogatták a hasonló kutatási dizájnnal ugyanazt a tanulási kimenetet mérő tanulmányokat, majd kiszámolták minden egyes tanulmányhoz tartozóan a korrelációs együtthatót $(r)$, végül ezekből egy közös együtthatót, amely jelen esetben az adott mủvészet és a mért kompetencia közötti összefüggés erősségét mutatja. A szignifikancia kiszámításához a populáció méretét szorozták a korrelációs együtthatóval.

A 266 oldalas, a megértést segítő grafikonokkal és ábrákkal bőven illusztrált könyv talán legnagyobb értéke a kvantitatív kutatások rendszerezett bemutatása, amely ugyanakkor jól áttekinthető (a szakirodalmat például az egyes fejezetekhez kapcsolódóan közli), és szigorú logikával felépített. Az eredmények röviden így foglalhatók össze. 


\section{A müvészeti nevelés és a nem müvészeti tárgyú tanulmányi képességek}

Az Egyesült Államokban a NEALS kutatáshoz - amely egy reprezentatív mintán végzett longitudinális vizsgálat volt - panelként kapcsolódott Catterall a müvészeti nevelés hatását vizsgáló korrelációs kutatása (1998). A metaanalízis során ezt további kutatási eredményekkel összegezve megállapítható, hogy azok a tanulók, akik nagy arányban vesznek részt müvészeti kurzusokon, magasabb tanulmányi teljesítményt érnek el, mint azok, akik kisebb arányban vagy egyáltalán nem, s ez igaz a magasabb és alacsonyabb szociokulturális környezetben is. Winner és társai azonban hangsúlyozzák, hogy a korreláció önmagában még nem világítja meg az okokat: például lehetséges, hogy a müvészetet tanuló gyerekek olyan családból származnak, amely támogatóan áll hozzá mind a mủvészeti, mind az akadémikus tanulmányokhoz; esetleg olyan iskolába járnak, mely mindkét területen nagyobb elvárást támaszt tanulóival szemben. Tehát nem bizonyított, hogy a múvészet okozza a jobb tanulmányi eredményeket. Már csak azért is óvatosnak kell lenni az eredmények értelmezésénél, mert egy, az Egyesült Királyságban végzett kutatás épp az ellenkezőjét mutatta: a müvészeti pályán tanuló diákok gyengébben teljesítettek az érettségi vizsgán (Harland, Kinder, Lord, Stott, Schagen és Haynes, 2000).

A zene erősíti az IQ-t, az előadói készséget, a fonológiai képességeket és a beszédértést zajos környezetben, s erősen feltételezhetö, hogy segíti az idegennyelvtanulást. Javíthatja továbbá a verbális képességeket (beleértve az olvasást az írást és az idegennyelv-tanulást). Számos tanulmány a zene pozitív hatását mutatja ki a térlátásra, de az egyetlen longitudinális vizsgálat nem mutat hosszú távú hatást. Nincs arra vonatkozó evidencia, hogy a zene fejlesztené a matematikai képességet.

A színházi nevelés egyik fajtája, az osztálytermi dráma (classroom drama) erősíti a verbális képességeket, de nincs meggyőzően kimutatható kapcsolat a színházi nevelés és az általános tanulmányi képességek között.

Két kutatás azt bizonyítja, hogy a vizuális nevelésben részesülőknek jobb a geometriai gondolkodása, de az oksági összefüggés nem bizonyított. Tipikusan közeli transzferhatást mutat ki egy tanulmány a müvészeti munkák alapos megfigyelése (close observation) és a természettudományos megfigyelési képesség között.

A tánc területén nem fedezhető fel hatás a matematikai vagy verbális képességekre, egyes tanulmányok szerint hatással van a térlátási képességekre, de e tanulmányok kis száma nem enged meg messzemenő következtetéseket.

\section{Gondolkodás és kreativitás}

Kevés kutatás vizsgálja a kreativitás növekedését tánccal vagy színházi neveléssel kapcsolatban, a kisszámú statisztikai adat pedig nem engedi meg a következtetések általánosítását. A sokoldalú művészeti nevelés terén tett kutatások sem bizonyítot- 
tak oksági összefüggést a kreativitás és a problémamegoldás területén. A kritikus gondolkodás és a müvészet közötti kapcsolatot egyetlen tanulmány sem vizsgálta a kutatásba bevontak közül!

\section{Szociális és viselkedési kompetenciák}

Empirikus tanulmányok azt mutatják, hogy müvészeti kurzusokba bevont tanulók motiváltabbak az általános tanulásban, ezek azonban korrelációs tanulmányok, amelyek nem engedik meg azt a következtetést, hogy az erösebb motiváció oka lenne a mủvészeti nevelés. Más szociális képességek (önbizalom, önkép, kommunikációs és együttmüködési képességek, empátia, mások érzelmeinek figyelembe vétele, saját érzelmek kifejezése és szabályozása) esetén is csupán törekvés van a müvészeti nevelés pozitív hatásának igazolására. A leginkább biztató eredmények ezen a téren az osztálytermi drámával kapcsolatban születtek (252-256. o.).

Az eredmények összegzése után látszik, hogy az eleinte nagynak vélt populáció (507 kutatás) mennyire kevés: „Számos tanulási kimenet esetén nem több, mint 2-3 tanulmány állt rendelkezésre. A müvészeti nevelésre irányuló kutatás a neveléstudományi kutatások csupán apró szelete" (256. o.).

Ha rátekintünk az eddig leírtakra, akkor egy olyan elméletirányított kutatást látunk, amely egy széles körben jelen lévő (például politikusok nyilatkozataiban vagy az OECD országok tanterveiben), de kevéssé tudatosított szociális konstrukcióra hívja fel a figyelmet, vagyis arra, hogy az élethosszig tartó tanulás paradigmájában a mủvészeti nevelés feladatát sokan a nem müvészeti tanulási kimenetekre tett hatásban látják. A kutatás tulajdonképpeni célja, és egyben egyik eredménye is, hogy ezt a felfogást tudatossá teszi, az erre vonatkozó nézeteket összegyüjti, rendszerezi, értelmezi, majd ebbe a rendszerbe belehelyezi az empirikus vizsgálatot. A fenti konstrukciót ugyanis empirikusan a transzfervizsgálatok bizonyíthatják. Ezért a kutatók minél nagyobb számú adatot gyüjtöttek össze a témában, hogy öszszegezni tudják a rendelkezésre álló tudást. A metaanalízis ennek az összegzésnek az eredményét teszi számszerüvé. A kutatás tehát lényegében egy elmélet felülvizsgálatára irányul.

A REAP kutatás eredményeit bemutató konferencián Rosenthal és Hetland (2001) a metaanalízis kritikájáról szóló fejezetet Sir Winston Churcill híres mondásával vezetik be „Senki nem állítja, hogy a demokrácia tökéletes, vagy csalhatatlan. Éppenséggel úgy tudjuk, hogy a demokrácia a legrosszabb államforma, leszámítva az összes többit, amellyel eddig próbálkozott az emberiség." Ezt követően számos kritikai szempontot sorolnak fel. A legfontosabbak: a mintavétel torzítása, a metaanalízis során elvesző információk, a különböző kutatások metodikai sokszínüsége, amely gyakran nem engedi meg a számszerü összegzést, valamint a jó és gyenge minőségü kutatások eredményének összegződése. 
A metaanalízisnek számos pozitív vonása is van: orientál például a jövőbeni kutatások tekintetében, feltárja a hiányosságokat, és ma, amikor egyre több kutatási eredmény lát napvilágot, világossá teheti a pozitív tendenciákat, trendeket. Mindenképpen világos, erős képet ad egy adott területről.

\section{A kvantitatív kontra kvalitatív kérdés}

A kvantitatív kontra kvalitativ kérdés a kutatási design egyik legproblematikusabb pontja. James $S$. Catterall rendkívül éles kritikát fogalmaz meg a kvalitatív kutatások kizárása miatt. „A Winner és Cooper (2000) fejezet, és a REAP-beszámoló mint egész, jogaitól foszt meg nagyon sok kutatási modellt és az azokat szakértő módon gyakorlókat - antropológusokat, etnográfusokat, programértékelőket, müvészeti nevelés területén kutatókat és tanárokat is. Ezek a nem-kíséleti-kutatók (non-experimentalist) a müvészeti programok hatásainak megértéséhez sok utat sorakoztatnak fel. Igazolt módszerek, mint a megfigyelés, a résztvevői megfigyelés, kliens- és szolgáltató felmérések, intenzív interjúkutatás, sok szempontú lencsét alkalmazó triangulációs kutatás, a tanulói munkák tanulmányozása, csak néhány azok közül a módszerek közül, amelytől a REAP megvonta bizalmát." (Catterall, 2001, 33. o.).

Catterall nézetével szemben úgy vélem, Winnerék kutatása tökéletes korrektséggel hoz összhangba célt, kérdést és eszközt. Az alapvetően kvantitatívnak mondott kutatásnak jó adag kvalitatív eredménye is van, például a kutatások összegyüjtése, csoportosítása, értelmezése, eredményeinek rövid leírása. A könyv nem zárja ki a kvalitatív módszereket látóköréből, oldalakat szentelnek többek között a magyar DICE program bemutatásának. Ellen Winner, a könyv első szerzője a REAP-projektet követően egy kutatócsoporttal komoly kvalitatív kutatásba fogott bele a müvészeti nevelés hatásainak jobb megismerése érdekében, melynek eredménye a Studio Thinking (2007) címü könyv. Nem valószínü, hogy a kvantitatív módszerek iránti elfogultságból döntött volna a kvalitatív tanulmányok kizárása mellett. Sokkal inkább azért, hogy szigorúan objektív módon vizsgálja felül a múvészet transzferhatásaival kapcsolatos elképzeléseket, és ezáltal szembesítsen az alaptalan vagy túlzó elvárásokkal.

A kutatás gyenge pontja sokkal inkább az, hogy eleve olyan képességeket vizsgál, amelyek összetettek, tehát a számszerü mérés nehezen kivitelezhető a változók nagyon nagy száma miatt. A transzfer ráadásul igen nehezen bizonyítható (v.ö. 36. o.).

Vegyük például a kreativitást, amelynek támogatását az USA oktatási államtitkára elsősorban a müvészettől várja. Vegyünk egy olyan kreativitás modellt, amely a legújabb kutatásokat tükrözi. Collard é Looney (2014) Lucas, Claxton és Spencer (2013) nyomán 15 részképességet sorol fel öt csoportra bontva a kreativitás össze- 
tevőinek meghatározásakor. 15 részképesség mérése, azok bonyolult belső egymásra hatását is figyelembe véve rendkívül nehéz feladat.

A másik oldalon adott egy bizonyos müvészeti tevékenység, amelyröl bizonyítani szeretnénk, hogy fejleszti a kreativitást. Igen ám, de itt is számos változónk van, például az órák időtartama, a rendszeresség, az időszak, az előképzettség, a tanári módszerek, a gyerekek életkora, szociális helyzete, és további látens tényezők is lehetnek. A transzfer bizonyítása további nehézségek forrása. Tegyük hozzá, egy másik kreativitás-modellel dolgozó másik kutatás összevethetetlenné teszi az eredményeket. Így a metaanalízisig el sem jutunk. A kevés esetszámmal dolgozó, egyetlen kutatásra vonatkozó eredmények szignifikancia szintje pedig alacsony lesz.

Nem csodálkozhatunk hát azon, hogy a könyv meglehetősen kevés pozitív korrelációról, és ennél is kevesebb bizonyítható ok-okozati összefüggésröl tud beszámolni. Számos, egy területre vonatkozó, hasonló dizájnnal készült kutatás kell ahhoz, hogy érdemi eredményről beszélhessünk. Ilyen például Ann Podlozny (2001) tanulmánya, amely közel 200 kutatás vizsgálata után világos összefüggést állapított meg az osztálytermi dráma és hat verbális részképesség fejlődése között.

A könyv szerzőinek szándéka valójában nem a müvészet transzferhatásainak cáfolása. Sokkal inkább a müvészeti nevelés céljáról való gondolkodás megváltoztatása, amelyet a szerzők a kutatási eredmények összefoglalásakor világosan ki is mondanak: a müvészeti nevelés igazolását nem más területekre tett hatásában kell keresnünk, hanem a müvészi diszpozíciók (habits of mind) megismerésében és elfogadásában, amilyen például az alapos megfigyelés, az elképzelés, a kitartás, a kifejezés, az együttmüködés és a reflexió. „A müvészet pedig minden gyermek számára egy másik megismerési utat kínál, mint a tudomány. Mivel itt egy olyan terepen vannak, ahol nincsenek jó vagy rossz válaszok, ez felszabadítja a tanulókat a felfedezésben és kísérletezésben" - vallják. (20. o.)

A könyv címe is a fenti értelmezést erösíti meg. Az art for art's sake, avagy l'art pour l'art a XIX. század első felében megfogalmazódó eszme. Lényegi mondanivalója, hogy a müvészet önmagáért való, nem szükséges társadalmi, politikai, vallási vagy gazdasági szerepvállalással igazolnia létét. Nem egyszerúen esztétikai fogalom, hanem a müvészet függetlenségéért, a müvészi szabadságért folytatott küzdelem kifejezése. (Wiener, 1968; Tolcsvay, 2007).

Összegezve azt mondhatjuk, hogy az Az art for art sake? kérdése alapvetően a praktikum, külső hasznosság és a létezésben hordozott belső érték között feszül, $\mathrm{s}$ ezúttal nem a müvészetre, hanem a mủvészeti nevelésre vonatkozik. A szerzők célja tehát nem a müvészeti nevelés ellehetetlenítése, amikor a transzferhatások kimutatásának nehézségére hívják fel a figyelmet, hanem éppen védelme, a müvészeti nevelés visszahelyezése saját lényegéből fakadó jogaiba. 


\section{Irodalom}

Catterall, J. (1998): Involvement in the arts and success in secondary school. Americans for the Arts Monographs, 1/9 Washington DC.

Catterall, J. (2001): Main Points in Response to „Mute those Claims: No Evidence (Yet) For a Casual Link Between the Arts and Academic Achievement". In: Winner, E. Hetland, L. (szerk): Beyond the Soundbite: Arts Education and Academic Outcomes. Conference Proceedings from August 24-26, 2000. The J. Paul Getty Trust, Los Angeles, 32-38.

Collard, P. - Looney, J. (2014): Nurturing Creativity in Education. European Journal of Educatution 49. 3. sz. 348-364.

Harland, J. - Kinder, K. - Lord, P. - Stott, A. - Schagen, I. - Haynes, J. (2000): Arts Education in Secondary Schools: Effects and Effectivness. National Foundation for Educational Research, Slough.

Hetland, L. - Winner, L. (2001): The arts and academic achievement: What the evidence shows. Art Education Policy Review 102. 5. sz. 3-6.

Hetland, L. - Winner, E. - Veenema, S. - Sheridan, K. (2007): Studio Thinking: the Real Benefits of Visual Arts Education. College Press, New York.

Lucas, B. - Claxton, G. - Spencer, E. (2013): Progression in Student Creativity in School: First steps towards new forms of formative assessments. OECD Education Working Paper No. 86, OECD, Paris.

Podlozny, A. (2001): Strengthening Verbal Skills Through the Use of Classroom Drama: A Clear Link. A Summary of a Meta-Analytic Study. In: Winner, E. - Hetland, L. (szerk): Beyond the Soundbite: Arts Education and Academic Outcomes. Conference Proceedings from August 24-26, 2000. The J. Paul Getty Trust, Los Angeles. 99-108.

Rosenthal, R. - Hetland, L. (2001): Meta-Analysis: It's Use and Value in Arts Education Research. In: Winner, E - Hetland, L. (szerk): Beyond the Soundbite: Arts Education and Academic Outcomes. Conference Proceedings from August 24-26, 2000. The J. Paul Getty Trust, Los Angeles. 1-17.

Tolcsvay Nagy Gábor (2007, szerk.): Idegen szavak szótára. Osiris Kiadó, Budapest.

Wiener, P. P. (1968, szerk.): Dictionary of the History of Idea. Studies of Selected Pivotal Ideas. Charles Scribner's Sons, New York.

Winner, E. - Cooper, M. (2000): „Mute those Claims: No evidence (yet) for a causal link between arts study and academic achievement. Journal of Aesthetic Education, 34. 3/4.sz. 11-75.

Winner, E. - Hetland, L. (2001, szerk): Beyond the Soundbite: Arts Education and Academic Outcomes. Conference Proceedings from August 24-26, 2000. The J. Paul Getty Trust, Los Angeles.

Winner, E. - Goldstein, T. R. - Vincent-Lacrin, S. (2013): Art for art's sake? - the impact of arts education. Educational Research and Innovation. OECD Publishing, Paris, 266 oldal 